\title{
Effects of Mycorrhiza on the Growth and Productivity of Faidherbia albida (Del.) A. Chev.
}

\author{
${ }^{1}$ M.A. Shinkafi and ${ }^{2}$ A.M. Aduradola \\ ${ }^{1}$ Department of Forestry and Fisheries, Usmanu Danfodiyo University, Sokoto, Nigeria \\ ${ }^{2}$ Department of Forest Resources Management, Federal University of Agriculture, Abeokuta, Nigeria \\ [*Correspondence Address: walinshinkafi@ hotmail.com; $\mathbf{0}+\mathbf{2 3 4}(\mathbf{0}) \mathbf{8 0 3 6 9 8 3 2 8}$ ]
}

\begin{abstract}
The effects of mycorrhiza on growth and growth components of Faidherbia albida (Del.) A. Chev. was investigated in the semi arid environment of Sokoto State, Nigeria. A complete randomized block design with five replications and factorial combination of three watering regimes (daily for unstressed plant, twice weekly for partially stressed plants and once a week for moisture stressed plants) and three mycorrhizal treatments namely; endomycorrhizal plants, ectomycorrhizal plants and non mycorrhizal plants were used. Both the ecto and endo mycorrhizae enhanced morphological features of the plant including height, basal diameter, leaf number, leaf area, root length and dry weights as well as its moisture utilization efficiency. Therefore, the use of mycorrhiza is recommended for sustained production of high-grade seedlings of the apple ring acacia in the semi arid environment.
\end{abstract}

KEYWORDS: Faidherbia albida, mycorrhiza, morphology, moisture stress

\section{INTRODUCTION}

Faidherbia albida (Del.) A. Chev. (Apple ring acacia 0 is one of the multipurpose tree species in the West African sub region. Thus, the protective and productive roles of the species as a farm tree are well documented. In the semi arid regions it is known to be an important browse plant, particularly during the long dry season for its retained palatable foliage when other trees would have shed their leaves. However, its extreme poor performance in terms of slow growth and low survival rate in pot culture is a severe constraint to its widescale use (NARP, 1995). The general trend is that most stands die shortly after emergence and those that eventually survive grow very slowly in comparison with other species which calls for the adoption of effective measures to solve the problem.

Several reports from different parts of the world have shown that some tree species usually fail to establish unless they are inoculated with relevant mycorrhiza forming fungus (Spurr and Barnes, 1980; Vogt et al., 2007). This situation has been experienced in Nigeria where it has been observed that pine plantations could not establish unless the seedlings were infected with a suitable mycorrhiza (Odeyinde and Ekwebelem, 1982). The major benefit of mycorrhiza to forest trees is that they are highly efficient accumulators of nutrient ions and water in their rhizosphere. The nutrients and water become available to the host plant and to the fungus thereby enhancing nutrition, growth, dry matter production as well as ability to withstand drought (Luyindula and Haque, 1992; Vogt et al., 2005). This study determined the roles of mycorrhiza on the general morphology of the apple ring acacia, which are critical elements of productivity.

\section{MATERIALS AND METHODS \\ Inoculation of seedlings}

Crude inocula of Pisolithus tinctacrum and Thelephora terrestris were prepared following the procedure of Osonubi and Mulongoy (1991). Thereafter, healthy seeds of Apple ring acacia were soaked in boiling water for 5 minutes, rinsed with distilled water and then allowed to germinate in plastic trays containing sterilized soil previously steamed at $121^{\circ} \mathrm{C}$ for 3 hours or same soil inoculated with $50 \mathrm{~g} /$ tray of crude mycorrhizal inoculum. Two weeks after germination and confirmation of seedlings infection by the inoculants, both the inoculated and uninoculated seedlings were transplanted (one seedling/tray) into polythene bags measuring $20 \mathrm{~cm}$ diameter and $40 \mathrm{~cm}$ deep containing $4 \mathrm{~kg}$ of strealized sandy loam soil as recommended by Osundina (1995).

\section{Experimental Design}

Seedlings were grown at the Botanical garden of Usmanu Danfodiyo University Sokoto, Nigeria under an average day/night temperature of $43^{\circ} \mathrm{C}$ and relative humidity of $45 \%$. A complete 
randomized block design was used with five replications and factorical combination of three watering regimes (daily for unstressed plant, twice weekly for partially stressed plants and once a week for moisture stressed plants) and three mycorrhizal treatments namely; endomycorrhizal plants, ectomycorrhizal plants and non mycorrhizal plants. The seedlings were watered regularly for a period of 2 weeks before the drought stress treatment began. Soil moisture at pot capacity was $30 \pm(2) \%$.

Plant height, collar diameter, leaf number and leaf area were recorded on weekly basis to determine the effects of the treatments on such morphological features. Leaf area was determined using the relevant formular. At the end of the experiment (16 weeks after germination), leaf, shoot and root dry weights were determined after drying at $70 \%$ for 2 days. Total Nitrogen was also determined using Micro-Kjeldhal digestion method. Difference in growth parameter and dry matter production were tested for significance using analysis of variance(DMRT).

\section{RESULTS AND DISCUSSION \\ Morphological Features and Dry Matter Production}

During the experiment, some of the seedlings under drought stressed conditions died giving a mortality rate of about two percent non-inoculated plants (NMW1) but inoculation with mycorrhiza (ENM and ECM) improved growth even in moisture stressed conditions (watered once weekly). Seedlings inoculated with endomycrorrhiza (ENMP) recorded greater plant height, basal diameter, leaf number, leaf area, root length, total dry weight, shoot dry weight and root dry weight more than the plants inoculated with ecto-mycorrhiza (ECMP) as shown in Table 1. However, the result showed non significant $(\mathrm{P}>0.05)$ difference between moisture-stressed plants inoculated with either of the mycorrhizal type (ENMW, and $\mathrm{ECMW}_{1}$ ) in terms of plants height, basal diameter, shoot dry weight and root length. These findings support the observations made by Allen and Boosalis (1993) on A. auriculiformis, A. lebbeck and Leucocephala. Jasper et al. (1989) also found that root infection with mycorrhiza increases plant productivity and drought tolerance by improving phosphorus. Similarly, Levy et. al. (1983) and Read and Boyd
(1986) reported that mycorrhizal inoculation increased soil water extraction and root hydraulic conductivity.

The partially stressed $F$. albida plants that were watered twice a week (ENMW2 and ECMW2) were significantly higher in terms of root infection, growth and dry matter production than non-inoculated plants receiving the same watering frequency (NMW2). In this respect, the endomycorrhizal plants were still significantly $(\mathrm{P}<0.05)$ better than the ecto-mycorrhizal ones. Similarly, plants height, basal diameter, leaf number, leaf area and dry matter yield differed significantly $(\mathrm{P}<0.05)$ between unstressed endo, ecto and non mycorrhiza inoculated plants (ENMW3, ECMW3 and NMW3). In general, the interaction between mycorrhiza and moisture stress was significant $(\mathrm{P}<0.05)$ as a result of positive mycorrhizal effect on young seedlings of F. albida plants.

The increase in leaf area, basal diameter, plant height and total dry weight, recorded in this experiment can be attributed to mycorrhizal ability to improve drought tolerance. Huang et al. (1985), Michealson and Rosendhal (1990), Osonubi and Mulougoy (1991) and Vogt (2003) also reported similar findings that mycorrhizal inoculation enhanced the morphological growth of A. nilotica, A. auriculiformis and L. leucocephala. According to these authors, growth depression by VAM inoculant is not usual. Growth depression in mycorrhiza inoculated A. Auriculoformis reported by Allen and Boosalis (1993) has been attributed to limited carbohydrate availability in the host plant (Vogt et al, 1982) suggesting that VAM inoculants may at times be parasitic. The interaction between these factors (mycorrhiza and drought stress) resulted in a positive growth performance of all the plant parameters measured, indicating that both endo and ecto mycorrhiza were not parasitic that could bring about growth depression in the case of $F$. albida. 
Shinkafi \&. Aduradola: Effects of Moisture and Mycorrhiza on Stomatal Conductance and Xylem Pressure Potential of...........

Table 1: Response of $F$. albida to moisture level and inoculation with mycorrihiza

\begin{tabular}{|c|c|c|c|c|c|c|c|c|c|}
\hline Treatment & $\begin{array}{l}\text { Plant } \\
\text { Height } \\
(\mathrm{cm})\end{array}$ & $\begin{array}{l}\text { Basal } \\
\text { diameter } \\
(\mathrm{cm})\end{array}$ & $\begin{array}{l}\text { Leaf } \\
\text { Number }\end{array}$ & $\begin{array}{l}\text { Leaf } \\
\text { area } \\
\left(\mathrm{cm}^{2}\right)\end{array}$ & $\begin{array}{l}\text { Shoot dry } \\
\text { weight } \\
\text { (g) }\end{array}$ & $\begin{array}{l}\text { Root } \\
\text { length } \\
(\mathrm{cm})\end{array}$ & $\begin{array}{l}\text { Total dry } \\
\text { weight } \\
\text { (g) }\end{array}$ & $\begin{array}{l}\text { Root dry } \\
\text { weighty } \\
\text { (g) }\end{array}$ & $\begin{array}{r}\text { Root } \\
\text { Infection } \\
(\mathrm{cm})\end{array}$ \\
\hline$\overline{\mathrm{NMW}_{1}}$ & $0.02^{\mathrm{g}}$ & $0.08^{C}$ & $7.20^{\mathrm{g}}$ & $2.38^{\mathrm{g}}$ & $0.004^{d}$ & $10.98^{\mathrm{g}}$ & $0.005^{\mathrm{h}}$ & $0.0002^{a}$ & $0.000^{\mathrm{e}}$ \\
\hline $\mathrm{NMW}_{2}$ & $10.96^{\mathrm{f}}$ & $0.09^{d}$ & $21.60^{\mathrm{e}}$ & $2.61^{f}$ & $0.005^{\mathrm{d}}$ & $13.20^{\mathrm{f}}$ & $0.008^{g}$ & $0.0002^{\mathrm{g}}$ & $0.000^{\mathrm{e}}$ \\
\hline $\mathrm{NMW}_{3}$ & $15.26^{\mathrm{e}}$ & $0.10^{d}$ & $30.20^{\mathrm{d}}$ & $3.32^{\mathrm{d}}$ & $0.005^{\mathrm{d}}$ & $18.22^{\mathrm{e}}$ & $0.0011^{f}$ & $0.0002^{f}$ & $0.000^{\mathrm{e}}$ \\
\hline $\mathrm{ENMW}_{1}$ & $15.06^{\mathrm{e}}$ & $0.10^{\mathrm{d}}$ & $30.60^{d}$ & $3.62^{c}$ & $0.0031^{\mathrm{c}}$ & $25.60^{d}$ & $0.0042^{c}$ & $0.0011^{\mathrm{c}}$ & $25.000^{c}$ \\
\hline $\mathrm{ENMW}_{2}$ & $32.80^{\mathrm{c}}$ & $0.15^{b}$ & $51.00^{\mathrm{b}}$ & $4.51^{b}$ & $0.0107^{\mathrm{a}}$ & $32.46^{\mathrm{h}}$ & $0.0189^{a}$ & $0.0186^{\mathrm{a}}$ & $32.000^{b}$ \\
\hline $\mathrm{ENMW}_{3}$ & $38.78^{a}$ & $0.18^{\mathrm{g}}$ & $59.20^{\mathrm{a}}$ & $6.93^{\mathrm{a}}$ & $0.0093^{a b}$ & $37.66^{\mathrm{a}}$ & $0.00136^{\mathrm{c}}$ & $0.00043^{c}$ & $40.000^{\mathrm{a}}$ \\
\hline $\mathrm{ECMW}_{1}$ & $15.00^{\mathrm{e}}$ & $0.09^{d}$ & $13.20^{\mathrm{f}}$ & $3.11^{\mathrm{e}}$ & $0.0025^{\mathrm{c}}$ & $25.28^{d}$ & $0.0011^{\mathrm{f}}$ & $0.005^{f}$ & $21.000^{\mathrm{d}}$ \\
\hline $\mathrm{ECMW}_{2}$ & $28.00^{\mathrm{d}}$ & $0.13^{c}$ & $29.40^{\mathrm{d}}$ & $3.64^{\mathrm{c}}$ & $0.0090^{b}$ & $27.24^{\mathrm{c}}$ & $0.0167^{b}$ & $0.0077^{b}$ & $26.400^{c}$ \\
\hline $\mathrm{ECMW}_{3}$ & $36.20^{\mathrm{b}}$ & $0.16^{b}$ & $32.60^{\mathrm{d}}$ & $4.35^{\mathrm{b}}$ & $0.0036^{c}$ & $32.16^{\mathrm{b}}$ & $0.0096^{\mathrm{d}}$ & $0.0058^{c}$ & $33.000^{b}$ \\
\hline
\end{tabular}

Means along the same row with the same superscript(s) are not significantly different $(\mathrm{P}>0.05)$ DMRT 


\section{CONCLUSIONS \& RECOMMENDATIONS}

Interaction between mycorrhizae and moisture resulted in enhanced growth of $F$. albida plants, indicating that both endo and ecto mycorrhizas were not parasitic but growth promoters. However, endomycorrhiza was found to exert more influence than ecto-mycorrhiza in respect of the morphological characteristics of seedlings. It is therefore recommended that:

i) The use of mycorrhiza, particularly the endomycorrhiza, be employed in raising the seedlings of $F$. albida to reduce the persistent high mortality rates experienced over the years in its nursery beds;

ii) Daily watering of the $F$. albida nursery beds be ensured since it produces seedlings with the best morphological characteristics. In the event where there is scarcity of water, mychorrhiza should then be used to enhance drought tolerance;

iii) More research should be carried out to identify the fungi that has the ability to form mycorrhiza with the apple rings acacia as well as other plant species of multipurpose significance;

iv) Government and other relevant bodies should popularize the use of mycorrhiza in both tree and arable crops production. This will not only lead to the realization of the wider benefits of the fungus - root relationship but also a means of adopting environmentally friendly system of soil fertility management and hence sustainable crop production

\section{REFERENCES}

Allen, M.F. and Boosalis, M.G. (1993). Effects of some species of vesicular-abuscular mycorrhizal fungi on drought tolerance of winter wheat. New Phytol 93: 67 - 76.

Huang, R.S., Smith, W.K. and Yost, R.S. (1985). Influence of vesicular arbisucular mycorrhiza on growth, water relations and leaf orientation in leuceana leucocephala (Lam) Wit. New Phytol. 101: 229 - 243.

Jasper, D.A., Abbot, L.K. and Robbinson, A.D. (1989). Acacias response to additions of phosphorus and to inoculations with VA mycorrhiza fungi in soil stockpile during mineral sand and mining. Plant and Soils 115: $99-108$.
Levy, Y., Dood, D. and Krikun, J. (1983). Effect of irrigation, water salanity and rootstock on the vertical distribution of vesicular arbiscular mycorrhiza on citrus roots. New phytol. 99: 397-403.

Luyindula, N. and Haque, I. (1992). Effect of rhizobium inoculation and phosphorus on growth and nitrogen fixation in tree grown on vertisols. In K. Mulongoy, M. Gueye and D.S.F. Spencer (eds.) Biological nitrogen fixation and sustainability of tropical Agriculture. Weley and Sayec Glouchester, New York. Pp 109 -113.

Michealson, A. and S. Rosendahl (1990). The effect of VA mycorrhizal fungi phosphorus and drought stress on the growth of Acacia nilotica and leucacaena lucocephala seedlings. Plant and Soil. 124: 7-13.

NARP (1995). Priority Research Area in Forestry. University of Ibadan Press Nigeria. Pp $35-40$.

Odeyinde, M.A. and Ekwebelem, S.A. (1982). In search of a suitable pine mycorrhizal fungus in the high forest zone of Nigeria. For. Sci. 39: 93 -97 .

Osunobi. O. and Mulongoy, K. (1991). Response of two acacia species to drought and inoculation with ecto-mycorrhizal fungus. In D.L., Kieste, P.B. Cregan (eds). The rhizosphere and plant growth. Kluwer Academics Publishers, Dordecht. Pp 362 - 375.

Osundina, M.A. (1995). Response of seedling of Parkia biglobosa (African Locust Beam) to drought and inoculation with vesiculararbusucular mycorrhiza. Nig. J. Bot. 8: 1-10.

Read, D.J. and Boyd, R.C. (1986). Water relations of mycorrhizal fungi and their host plants. In P.C. Ayres and L. Boddy (eds). Water, fungi and Plants. Cambridge University Press, U.K.

Spurr, S.H. and Barnes, B.V. (1980). Forest Ecology. John Wiley and Sons, New York.

Vogt, K.A. (2003). Dynamics of Ectomycorrhiza in Abies amabilis stand: The Role of Cenococcum graniforms. Halartic Ecol. 24: 1-8.

Vogt, K.A., Grier, C.C. and Meir, C.E. (2007). Physological role in net primary production and nutrient cycling in abies amabilis ecosystems in western Washington. Ecol. 63(2): $350-370$. 